\title{
Kindling Induces the Long-lasting Expression of a Novel Population of NMDA Receptors in Hippocampal Region CA3
}

\author{
John E. Kraus, ${ }^{1}$ Geng-Chang Yeh, 2.a Douglas W. Bonhaus,, ${ }^{3.6}$ J. Victor Nadler,, ${ }^{1.2}$ and James O. McNamara ${ }^{1,23.4}$ \\ Departments of ${ }^{1}$ Neurobiology, ${ }^{2}$ Pharmacology, and ${ }^{3}$ Medicine (Neurology), Duke University Medical Center, Durham, \\ North Carolina 27710, and ${ }^{4}$ Department of Veteran Affairs Medical Center, Durham, North Carolina 27705
}

Kindling refers to a phenomenon in which repeated application of initially subconvulsive electrical stimulations produces limbic and clonic motor seizures of progressively increasing severity. Once established, the increased excitability is lifelong. Enhanced function of synapses using the NMDA subtype of glutamate receptor could contribute to the expression of the increased excitability. We previously found that CA3 pyramidal cells of hippocampus of kindled animals exhibit a selective and long-lasting (1 month) increased sensitivity to NMDA-evoked depolarization. The goal of this study was to develop a molecular explanation of the enhanced sensitivity to NMDA. We used radioligand binding studies of membranes isolated from microdissected regions of hippocampus including fascia dentata, CA3, and CA1. We also used quantitative in situ hybridization with subtypespecific riboprobes or oligonucleotides to determine whether increased expression of one or more of the genes encoding NMDA receptors was present in hippocampal granule and pyramidal cells of kindled animals. When studied $28 \mathrm{~d}$ after the last evoked seizure, we found that kindling induced a 2.8-fold increase in the number of binding sites for the competitive NMDA receptor antagonist 3-[( \pm )-2-(carboxypiperazine-4-yl)][1,2-3 $\mathrm{H}$-]propyl-1-phosphonic acid $\left({ }^{3} \mathrm{H}-\right.$ CPP). This increase was confined to region CA3 within the hippocampus. Similar, though much smaller, changes were detected $24 \mathrm{hr}$ after the last evoked seizure. Surprisingly, no changes in the binding of another competitive NMDA receptor antagonist, cis-4-(phosphonomethyl)-2- ${ }^{-} \mathrm{H}$-piperidinecarboxylate ( $\left.{ }^{3} \mathrm{H}-\mathrm{CGS}-19755\right)$, were detected at either time point in any hippocampal region. Transcript levels of the NMDA receptor genes NMDAR1, NR2A, NR2B, NR2C, and NR2D and a glutamate-binding protein (GBP) were not altered by kindling.

These findings demonstrate that kindling induces the expression of an NMDA receptor that is novel in that it is recognized by ${ }^{3} \mathrm{H}-\mathrm{CPP}$ but not by ${ }^{3} \mathrm{H}-\mathrm{CGS}-19755$. The molecular basis of this novel NMDA receptor is not determined by differential expression of mRNA transcripts of known NMDA

\footnotetext{
Received Oct. 6, 1993; revised Dec. 16, 1993; accepted Dec. 31, 1993.

J.E.K. and G.-C.Y. contributed equally to this work. We thank Yoshinori Watanabe for sectioning and processing of frozen tissue, Peiyuan F. Hsieh and Melissa Hayden for help in surgery and stimulation of the animals, and Nina Tang for assistance with oligonucleotide synthesis. This study was supported by NIII Grants NS 17771 and NS 7 R29 NS27311-04.

Present address: Department of Pediatrics and Nature Product Medical Institute, Taipei Medical College, Taiwan.

Present address: Department of Neuroscience, Syntex, Palo Alto, California. Copyright (C) 1994 Society for Neuroscience $0270-6474 / 94 / 144196-10 \$ 05.00 / 0$
}

receptor genes. The direction, time course, and location of the kindling-induced increase in ${ }^{3} \mathrm{H}$-CPP binding suggest that this novel receptor may underlie the increased sensitivity of CA3 neurons to NMDA observed in kindled animals.

[Key words: kindling, NMDA receptor, in situ hybridization, hippocampus, plasticity, epilepsy]

Kindling is an animal model of epilepsy in which periodic application of an initially subconvulsive electrical stimulus eventually results in intense limbic and clonic motor seizures (Goddard et al., 1969; McNamara et al., 1992). Once established, the increased excitability appears to persist for the life of the animal. Understanding the pathophysiology of the enduring hyperexcitability in molecular terms may facilitate development of selective and effective anticonvulsants.

Increasing evidence suggests that enhanced function of synapses using the NMDA subtype of glutamate receptor contributes to the expression of the hyperexcitability. Both competitive and uncompetitive antagonists of the NMD $\Lambda$ receptor inhibit kindled seizures (Callaghan and Schwark, 1980; Peterson et al., 1983, 1984; Holmes and Goddard, 1986; Cain et al., 1988; McNamara et al., 1988a,b; Holmes et al., 1990; Löscher and Hönack, 1991). Electrophysiologic analyses disclose that NMDA receptor-dependent synaptic responses are more readily evoked in dentate granule cells of kindled than control animals (Mody et al., 1988). Biochemical studies disclose a selective and longlasting enhanced sensitivity to NMDA-evoked depolarization in hippocampal slices of kindled animals (Morrisett et al., 1989, 1990) indicative of a change intrinsic to NMDA-receptive neurons. Grease gap studies subsequently localized the enhanced sensitivity to NMDA to the hippocampal CA3 pyramidal cells of kindled animals (Martin et al., 1992). Whole-cell patch-clamp and single-channel recordings of granule cells disclosed increases of mean open time and reduced sensitivity to $\mathrm{Mg}^{2+}$ block in slices isolated $\mathbf{1 - 3} \mathrm{d}$ after the last kindled seizure (Köhr et al., 1993).

Both the long-lasting enhanced sensitivity of CA3 pyramidal cells to NMDA and the altered properties of NMDA receptor channels identified shortly after the last kindled seizure are consistent with a modification intrinsic to the NMDA receptor itself. Recent molecular cloning studies have shown that the NMDA receptor channel is a heteromeric complex whose complement of subunit proteins determines its functional properties, including sensitivity to agonist (Moriyoshi et al., 1991; Ikeda et al., 1992; Kutsuwada et al., 1992; Meguro et al., 1992; Monyer et al., 1992; Nakanishi, 1992; Deuchars and Thomson, 1993; Ishii et al., 1993). Additionally, the sequence of a glutamatebinding protein (GBP) associated with a reconstituted NMDA 
receptor has been reported (Kumar et al., 1991). We previously found increased numbers of NMDA receptors and the allosterically linked glycine receptor in membranes isolated from the hippocampus 1 month after the last kindled seizure (Yeh et al., 1989). The goals of the present study were to determine the anatomic locale and time course of the kindling-induced changes in NMDA receptor binding and whether kindling was associated with increased expression of one or more of the genes encoding NMDA receptors.

Bricf accounts of this work have appeared previously (Kraus et al., 1993).

\section{Materials and Methods}

Kindling. Adult male Sprague-Dawley rats weighing at least $250 \mathrm{gm}$ underwent stereotactic implantation of a bipolar stimulating/recording electrode in the right amygdala under pentobarbital anesthesia using the following coordinates with instrument zero as reference: AP $+3.0 \mathrm{~mm}$, ML $4.8 \mathrm{~mm}$, and DV $2.3 \mathrm{~mm}$ below dura. After a postoperative recovery period of at least $7 \mathrm{~d}$, animals were stimulated twice daily (a $1 \mathrm{sec}$ train of $1 \mathrm{msec}$ biphasic rectangular pulses delivered at a frequency of $60 \mathrm{~Hz}$ ) at an intensity of the initial threshold afterdischarge. Stimulations were administered until the animals had exhibited at least three class 4 or class 5 seizures in which forelimb clonus, rearing, and/or falling were seen (Racine, 1972) and which lasted at least $20 \mathrm{sec}$. Control animals underwent electrode implantation but were not stimulated.

Dissection and membrane preparation. Rats were anesthetized and killed either $24 \mathrm{hr}$ or $28 \mathrm{~d}$ after the last electrically evoked seizure and the hippocampi were removed by blunt dissection. Hippocampi were cut into $700-\mu \mathrm{m}$-thick transverse sections on a tissue chopper. Hippocampal slices were microdissected in ice-cold $5 \mathrm{~mm}$ Tris acetate buffer, $\mathrm{pH} 7.4$, that contained $10 \mathrm{~mm}$ EDTA. Slices were visualized under a dissecting microscope and the hippocampal formation was dissected into fascia dentata (FD), CA3, and CA1. Microdissected hippocampal regions from two kindled or two control animals were pooled. To reduce the concentration of endogenous amino acids, membranes were isolated in the following manner (Bonhaus et al., 1989). Hippocampal regions were homogenized with a Polytron (setting 6 for $10 \mathrm{sec}$ ) in $50 \mathrm{~mm}$ Tris acetate $/ 10 \mathrm{mM}$ EDTA, pH 7.4. After centrifugation $(23,000 \times g$ for 20 $\min$ at $4^{\circ} \mathrm{C}$ ), the membranes were washed by eight additional cycles of homogenization, resuspension in fresh buffer, and centrifugation. The membranes were frozen in a methanol bath chilled with solid $\mathrm{CO}_{2}$ and thawed at room temperature prior to the third and fourth centrifugations. Prior to the fifth centrifugation, the membranes were incubated for $15 \mathrm{~min}$ at $37^{\circ} \mathrm{C}$. The fifth through ninth washes were performed with a $50 \mathrm{~mm}$ Tris acetate buffer, $\mathrm{pH} 7.4$, that did not contain EDTA. Membranes were stored frozen after the third centritugation $\left(-80^{\circ} \mathrm{C}\right)$ until the day of the binding experiment.

\section{$N M D A$ receptor antagonist binding assays}

${ }^{3} \mathrm{H}$-CPP binding assay. $\left[{ }^{3} \mathrm{H}\right] \mathrm{CPP}$ (New England Nuclear/DuPont, Boston, MA) binding was measured in $1 \mathrm{ml}$ of $50 \mathrm{~mm}$ Tris acetate buffer, $\mathrm{pH}$ 7.4. Binding isotherms were generated by incubating membranes with $40 \mathrm{~nm}{ }^{3} \mathrm{H}-\mathrm{CPP}$ and nine concentrations (0-1000 nM) of nonradioactive CPP (Tocris Neuramin, Bristol, England) at room temperature for $40 \mathrm{~min}$. Nonspecific binding was determined by incubation of radioactive ligand with $100 \mu \mathrm{M}$ nonradioactive ligand. Incubations were terminated by centrifugation $(10,000 \times g, 10 \mathrm{~min})$. Pellets were rinsed with ice-cold $5 \mathrm{~mm}$ Tris acetate $(2 \mathrm{ml} \times 3)$. Pellets were solubilized in $100 \mu \mathrm{l}$ of Solvable (DuPont, Boston, MA), $2 \mathrm{ml}$ of scintillation fluid was added to each tube, and the samples were counted.

${ }^{3} \mathrm{H}$-CGS-19755 binding assay. [ $\left.{ }^{3} \mathrm{H}\right] \mathrm{CGS}-19755$ (New England Nuclear/DuPont, Boston, MA) binding was measured in $1 \mathrm{ml}$ of $50 \mathrm{~mm}$ Tris acetate buffer, $\mathrm{pH} 7.4$. For membranes isolated $28 \mathrm{~d}$ after the last kindled seizure, binding isotherms were generated by incubating membranes with $20 \mathrm{nM}^{3} \mathrm{H}-\mathrm{CGS}-19755$ and nine concentrations $(0-1000 \mathrm{~nm})$ of nonradioactive CGS-19755 (Ciba Geigy, Summit, NJ) at room temperature for $40 \mathrm{~min}$. For membranes isolated $24 \mathrm{hr}$ after the last kindled seizure, specific CGS-19755 binding was measured by incubating membranes in $1 \mathrm{ml}$ of $50 \mathrm{~mm}$ Tris acetate buffer, pH 7.4, with $20 \mathrm{~nm}{ }^{3} \mathrm{H}$ CGS-19755 and three concentrations of nonradioactive CGS-19755 (200 $\mathrm{nM}, 600 \mathrm{nM}$, and $1000 \mathrm{nM}$ ) at room temperature for $40 \mathrm{~min}$. Incubations were terminated as above. Nonspecific binding was deter- mined by the incubation of radioactive ligand with $100 \mu \mathrm{M}$ nonradioactive ligand.

NMDA-displaceable ${ }^{3} \mathrm{H}$-glutamate binding to whole hippocampal membranes. Assays were done using whole hippocampal membranes isolated $28 \mathrm{~d}$ after the last stimulus-evoked seizure. Binding was mea-

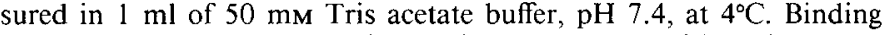
isotherms were generated by incubating membranes with various concentrations (10-600 nм) of ${ }^{3} \mathrm{H}$-glutamate (American Radiolabeled Chemicals Inc., St. Louis, MO) in the absence and presence of $100 \mu \mathrm{M}$ (for 10-100 nM ${ }^{3} \mathrm{H}$-glutamate) or 300 $\mu \mathrm{M}$ (for 200-600 nM ${ }^{3} \mathrm{H}$-glutamate) NMDA. Incubations were terminated after $10 \mathrm{~min}$ as described above. Antagonist inhibition of glutamate-stimulated ${ }^{3} \mathrm{H}$ - TCP hinding. Assays were done using whole hippocampal membranes isolated $28 \mathrm{~d}$ after the last stimulus-evoked seizure. ${ }^{3} \mathrm{H}-\mathrm{N}$-(1-[thienyl]cyclohexyl)piperidine $\left({ }^{3} \mathrm{H}-\mathrm{TCP}\right)$ (New England Nuclear/DuPont, Boston, $\mathrm{M} \Lambda$ ) binding

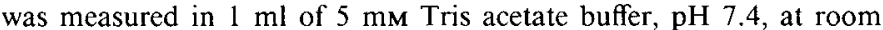
temperature. Reactions contained $2.5 \mathrm{nM}{ }^{3} \mathrm{H}-\mathrm{TCP}, 10 \mu \mathrm{M}$ glutamate, 3 $\mu \mathrm{M}$ glycine, and varying concentrations of antagonist $(0-100 \mu \mathrm{M})$. Reactions were terminated after $16 \mathrm{~min}$ by vacuum filtration using a Skatron cell harvester and Skatron filters. Nonspecific binding was determined by incubation of radioactive TCP with $1.25 \mu \mathrm{M}$ nonradioactive TCP.

Protein was determined by the method of Lowry et al. (1951).

Binding data analysis. Binding data were analyzed by nonlinear curve fitting to determine the number of bindings sites $\left(B_{\max }\right)$ and affinity $\left(K_{D}\right)$ for each ligand. Computer programs utilized for data analysis were LigAND (McPherson, 1985) and INPLOT (GraphPad, San Diego, CA). Both programs fit the data to a rectangular hyperbola (binding isotherm) described by the equation $Y-\left(B_{\max } \cdot X\right) /\left(K_{D}+X\right)$, where $Y$ is the specific bound ligand in units of $\mathrm{pmol} / \mathrm{mg}$ protein and $X$ is the ligand concentration in units of nM.

\section{Preparation of riboprobes for use in in situ hybridization}

NMDA receptor subclone preparation. Subclones containing regions of specific NMDA receptor genes were prepared as follows. (1) For NMDAR 1, a fragment spanning nucleotides 346-1181 was excised from the $5^{\prime}$ end of the full-length rat NMDAR I cDNA (gift of Shigetada Nakanishi, Kyoto University) and inserted into pBluescript (Stratagene, La Jolla, CA). Riboprobe generated from this fragment of the NMDAR 1 cDNA contains sequence common to all known splice variants of NMDAR1. (2) For NR2A, primers for use in the polymerase chain reaction (PCR) were synthesized to amplify the region spanning nucleotides $3425-4474$ of the NR2A gene. Specifically, primers used were CCACATGCCACAGGGAGCCACATA and CCCGACTGTCCCTGGAGCAATATG. The template used in the PCR was rat genomic DNA. The PCR was allowed to go through 30 cycles as follows: $45 \mathrm{sec}$ at $92^{\circ} \mathrm{C}$ (denaturation), $1 \mathrm{~min}$ at $61^{\circ} \mathrm{C}$ (annealing), and $1 \mathrm{~min}$ at $72^{\circ} \mathrm{C}$ (elongation). Reaction products were fractionated on a $1 \%$ agarose gel. A single product of expected size ( 1050 base pairs) was obtained and eluted from the gel. This fragment was subcloned into the TA cloning vector (Invitrogen, San Diego, CA). (3) For NR2B, primers for use in PCR were made to amplify the region spanning nucleotides $4021-4542$ of the NR2B gene. Primers used were GTGAGCCIGAAAGACAAGGGCCGA and CCCGTACCCACCTTAACCTCTCTC. Template for the PCR was rat genomic DNA. The PCR conditions were identical to those for $\mathrm{NR} 2 \mathrm{~A}$, except that the annealing temperature was $63^{\circ} \mathrm{C}$. Products were run on a $1 \%$ agarose gel, a single product of the expected size (522 base pairs) was eluted from the gel, and this fragment was inserted into the TA cloning vector. (4) For NR2C, primers for use in the PCR were made to amplify the region spanning nucleotides 1622-2584 of the NR2C cDNA. Primers used were TGGTATCAAGGAGCAACGGCACCG and AGTCCAGCTGGGATGAGTTGGGCA. Template for the PCR was CDNA made from polyA+ RNA isolated from rat cerebellum. The PCR conditions were identical to those for NR2A, except that the annealing temperature was $55^{\circ} \mathrm{C}$. Products were run on a $1 \%$ agarose gel, and a band of the expected size ( 963 base pairs) was eluted from the gel and inserted into the TA cloning vector. The identity of the subcloned products for NR2A, NR2B, and NR2C was confirmed by proper size, restriction enzyme mapping, and in situ hybridization of riboprobe made from the plasmids to coronal and horizontal rat brain sections. Hybridization with antisense probe showed patterns of expression consistent with those published by Monyer et al. (1992) and by Ishii et al. (1993). Hybridization with sense probe showed no specific binding. Glutamate-binding protein (GBP) riboprobe was prepared from 
Table 1. Effects of kindling on ${ }^{3} \mathrm{H}-\mathrm{CPP}$ binding in different hippocampal regions, $28 \mathrm{~d}$ after the last kindled seizure

\begin{tabular}{|c|c|c|c|c|c|c|}
\hline & \multicolumn{2}{|l|}{ FD } & \multicolumn{2}{|l|}{$\mathrm{CA} 3$} & \multicolumn{2}{|l|}{ CAl } \\
\hline & $B_{\max }$ & $K_{D}$ & $B_{\max }$ & $K_{D}$ & $B_{\max }$ & $K_{D}$ \\
\hline Control & $2.5 \pm 0.6$ & $434 \pm 130$ & $1.3 \pm 0.07$ & $192 \pm 43$ & $2.9 \pm 0.3$ & $251 \pm 64$ \\
\hline Kindled & $2.5 \pm 0.2$ & $412 \pm 125$ & $3.7 \pm 0.5^{*}$ & $561 \pm 104^{*}$ & $3.5 \pm 0.3$ & $324 \pm 58$ \\
\hline
\end{tabular}

Values are mean \pm SE of eight pairs of pooled membranes prepared from 16 pairs of control and kindled animals $\left({ }^{3} \mathrm{H}-\right.$ CPP in CA3 and CA 1) or of four pairs of pooled membranes prepared from eight pairs of control and kindled animals ( ${ }^{3} \mathrm{H}-\mathrm{CPP}$ in FD, and ' $\mathrm{H}$-CGS-19755). The unit of $K_{D}$ is nM; the unit of $B_{\max }$ is pmol/mg protein.

* The $B_{\max }$ and $K_{f}$ are significantly greater in CA3 of kindled animals than control animals $\left[B_{\max }: p=0.00005\right.$, two-way ANOVA (region $\times$ treatment) with post hoc Scheffe's test; $K_{j}: p=0.001$, two-way ANOVA (region $\times$ treatment) with post hoc Scheffé's test].

a plasmid containing the full-length cDNA sequence of GBP (gift of Elias K. Michaelis, University of Kansas).

Riboprobe preparation. The plasmid containing the NMDAR 1 insert was linearized using KpnI (for T3 polymerase transcription of antisense riboprobe) or SacI (for T7 transcription of sense riboprobe). The plasmid containing GBP was linearized using SacIl (for T7 transcription of antisense riboprobe) or $\mathrm{KpnI}$ (for $\mathrm{T} 3$ transcription of sense riboprobe). The plasmids containing NR2A, NR2B, and NR2C were linearized using HindIII [for T7 polymerase transcription of antisense (NR2A, NR2B) or sense (NR2C) riboprobe] or NotI [for SP6 polymerase transcription of sense (NR2A, NR2B) or antisense (NR2C) riboprobe]. Both antisense and sense riboprobes were generated from the linearized plasmids using T7, T3, or SP6 polymerase and an in vitro transcription assay in the presence of ${ }^{35}$-rUTP. Antisense and sense riboprobes were hydrolyzed to fragments approximately 200 base pairs in length with sodium carbonate at $60^{\circ} \mathrm{C}$.

\section{In situ hybridization and quantitation of NMDA receptor transcript expression}

In situ hybridization. Rats were anesthetized and decapitated and the brains were removed and frozen by slow immersion in an isopentane/ dry ice bath. Brains were cut in coronal sections $20 \mu \mathrm{M}$ thick, placed on gel-coated slides, and fixed with $4 \%$ paraformaldehyde. Each slide contained three coronal sections to allow triplicate hybridization reactions. On the day of the experiment, sections were thawed gradually from $-80^{\circ} \mathrm{C}$ to room temperature, treated with Proteinase $\mathrm{K}(10 \mathrm{mg} / \mathrm{ml}$ in $10 \mathrm{mM} \mathrm{CaCl}_{2}$ ) at a concentration of $1 \mu \mathrm{l} / \mathrm{ml}$ in $100 \mathrm{~mm}$ Tris- $\mathrm{HCl} / 50$ mM EDTA, pH 8.0 , at $37^{\circ} \mathrm{C}$ for $10 \mathrm{~min}$, washed in DEPC-treated water for $1 \mathrm{~min}$, washed in $0.1 \mathrm{M}$ triethanolamine $/ 0.9 \% \mathrm{NaCl}, \mathrm{pH} 8.0$, for 3 $\mathrm{min}$, and then treated with acetic anhydride $(0.25 \% \mathrm{v} / \mathrm{v})$ for $10 \mathrm{~min}$. Sections were washed in DEPC-treated water for $5 \mathrm{~min}$, and then dehydrated through graded ethanols $(50 \rightarrow 70 \rightarrow 95 \%$ ). Radiolabeled probes were added at a concentration of $60 \mathrm{ng} / \mathrm{ml}$ to a hybridization cocktail containing 50\% deionized formamide, $8 \%$ dextran sulfate, $4 \times \mathrm{SSC}(0.6$ $\mathrm{M} \mathrm{NaCl}, 0.06 \mathrm{M}$ citric acid, $\mathrm{pH} 7.0$ ), $1 \times$ Denhardt's solution, $0.5 \mathrm{mg} /$ $\mathrm{ml}$ yeast tRNA, $0.5 \mathrm{mg} / \mathrm{ml}$ salmon sperm DNA, and $10 \mathrm{~mm}$ dithiothreitol (DTT). Sixty microliters of hybridization cocktail were added to each slide. Nonspecific hybridization was determined by hybridization of sections with sense probe. Sections were incubated for $16-18 \mathrm{hr}$ at $55^{\circ} \mathrm{C}$. Following hybridization, sections were rinsed twice for $10 \mathrm{~min}$ in $4 \times \mathrm{SSC}$ and treated with RNase $\mathrm{A}(20 \mu \mathrm{g} / \mathrm{ml})$ at $37^{\circ} \mathrm{C}$ for $30 \mathrm{~min}$. Cells were rinsed in $1 \times \mathrm{SSC}$ for $10 \mathrm{~min}, 0.1 \times \mathrm{SSC}$ at $55^{\circ} \mathrm{C}$ for $30 \mathrm{~min}$, and $0.1 \times \mathrm{SSC}$ for $10 \mathrm{~min}$ at room temperature. Sections were dehydratcd through graded ethanols and exposed to llyperfilm $\beta$-max (Amersham) for 2-4 d. Films were developed in Kodak D-19 (5 min) and fixed in Kodak fixer ( $5 \mathrm{~min}$ ).

In situ hybridization signal quantitation. All autoradiographs were digitized using the Image- 1 image analysis system (Universal Imaging, West Chester, PA). In each experiment, a slide having a series of known ${ }^{35}$ S-rUTP standards was exposed to the film. A logarithmic standard curve was generated from the standard slide allowing the conversion of gray values to counts per minute (cpm). For each slide, stratum granulosum in dentate gyrus (DG) and strata pyramidale in areas $C A 3$ and $\mathrm{CAl}$ were traced and the average cpm was recorded. Guidelines for tracing hippocampal regions were obtained from Paxinos and Watson (1986). Regions for triplicate sections were averaged to give a cpm value for each region for that slide. A constant corresponding to the nonspecific $\mathrm{cpm}$ value obtained from the digitized autoradiographs of sense probe hybridizations was subtracted from each cpm to give the final cpm value used in data analysis. Hippocampal regions ipsilateral and contralateral to the electrode were measured separately. For all probes examined, no significant differences were found between ipsilateral and contralateral hippocampal regions in kindled or control animals; hence, these values were pooled and analyzed together.

$N R 2 D$ oligonucleotide probe preparation and in situ hybridization. A 50 mer oligonucleotide specific for the NR2D gene mRNA (GTTATCCCAGGTGATGTTCATGAAGTACCTGTGCAGACTCTCCCCGCGGT) was synthesized and labeled using terminal transferase and ${ }^{35} S-$ dATP. Brain sections were prepared and treated prior to hybridization as described above. In situ hybridization was carried out using the protocol of Wisden et al. (1991). Hybridizations were donc on brain sections prepared from rats postnatal day (P) 10 as a positive control in these experiments and showed a pattern of expression consistent with that reported by Monyer et al. (1993). Hybridization of sections with labeled probe in the presence of $100 \times$ excess unlabeled probe showed no specific signal. Quantitation was not possible in kindled and control animals since the signal was not detectable in adult hippocampus.

\section{Results}

NMDA receptor antagonist binding in different hippocampal subregions $28 \mathrm{~d}$ and $24 \mathrm{hr}$ after the last kindled seizure

We have previously demonstrated that kindling increases the number of binding sites $\left(B_{\max }\right)$ for the competitive NMDA receptor antagonist ${ }^{3} \mathrm{H}-\mathrm{CCP}$ in membranes isolated from the entire hippocampal formation $28 \mathrm{~d}$ after the last kindled seizure (Yeh et al., 1989). To determine the regional location of this increased binding, ${ }^{3} \mathrm{H}$-CPP equilibrium binding isotherms were generated with membranes from microdissected regions isolated $28 \mathrm{~d}$ after the last kindled seizure. We found that the number of binding sites for ${ }^{3} \mathrm{H}$-CPP was markedly increased in membranes isolated from region CA 3 of kindled animals, with a $B_{\max }$ approximately 2.8 times higher than that of controls (Table 1). Additionally, the affinity of this ligand for the NMDA receptor was lower in region $\mathrm{CA} 3$ of kindled animals, as reflected by a threefold increase in the $K_{D}$. The increase in $B_{\max }$ and $K_{D}$ were identified in each of the eight experiments comparing binding isotherms in membranes isolated from CA3. Changes in $B_{\max }$ were restricted to area $\mathrm{CA} 3$, with no differences in ${ }^{3} \mathrm{H}$-CPP binding detected in membranes from either fascia dentata or CAl (Table 1, Fig. 1).

In a subset of experiments, binding assays for ${ }^{3} \mathrm{H}$-CPP and ${ }^{3}$ II-CGS-19755, another competitive NMDA receptor antagonist, were performed with aliquots of membranes isolated from the same kindled and control animals. Surprisingly, in contrast to ${ }^{3} \mathrm{H}$-CPP, no differences in either $B_{\max }$ or $K_{D}$ were found with ${ }^{3} \mathrm{H}$-CGS-19755 in any hippocampal subregion (Table 2). The average kindling-induced change in $B_{\max }$ in region CA3 was significantly greater for ${ }^{3} \mathrm{H}-\mathrm{CPP}(2.23 \pm 0.6 \mathrm{pmol} / \mathrm{mg}$ protein $)$ 

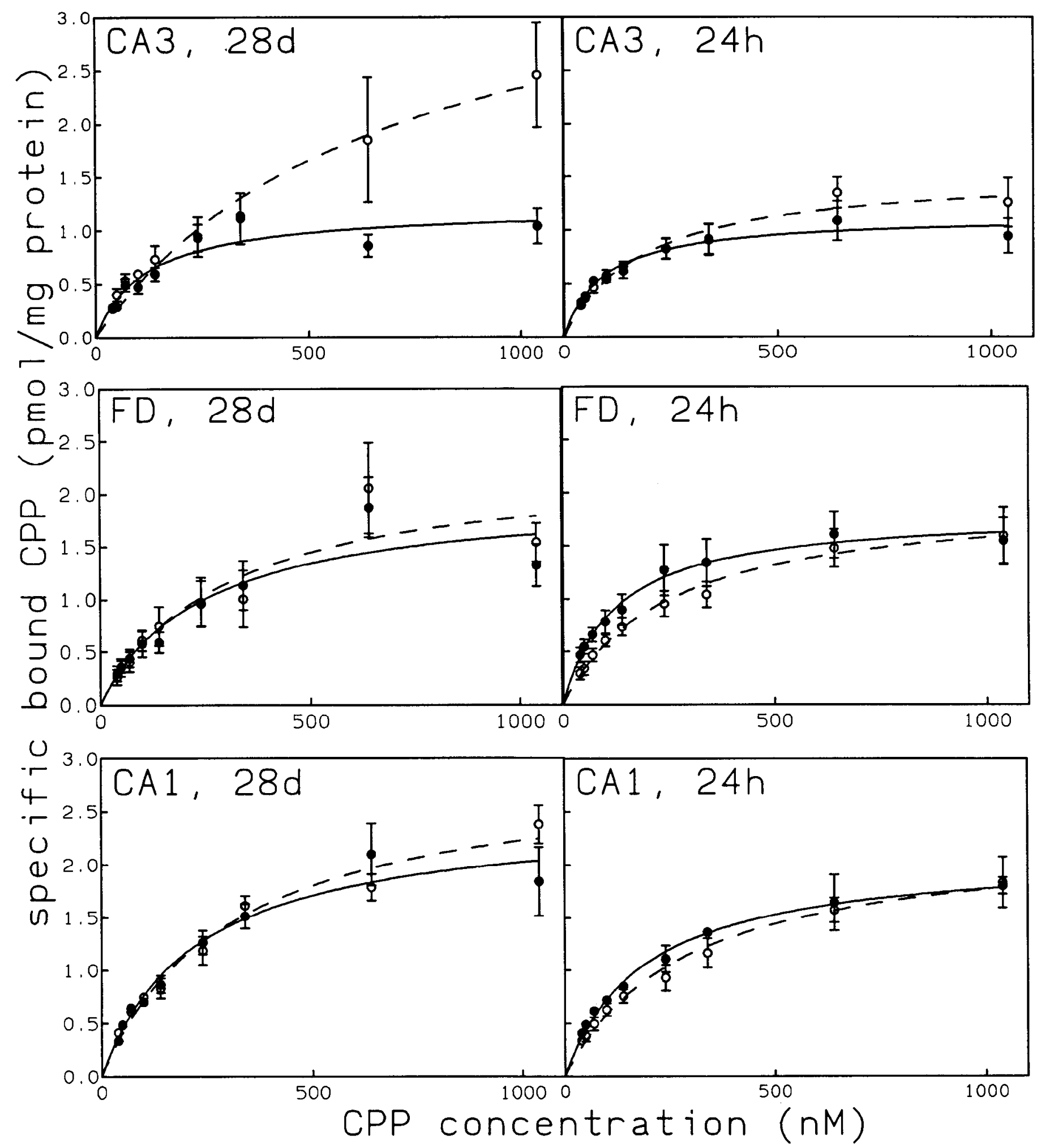

Figure 1. Average ${ }^{3} \mathrm{H}$-CPP binding isotherms generated on microdissected hippocampal membranes $28 \mathrm{~d}$ and $24 \mathrm{hr}$ after the last kindled seizure. Solid circles, solid lines, control; open circles, dashed lines, kindled. $n=4,28 \mathrm{~d} ; n=5,24 \mathrm{hr}$ (except control CA3, $n=4$ ).

than for ${ }^{3} \mathrm{H}-\mathrm{CGS}-19755(-0.0075 \pm 0.3 \mathrm{pmol} / \mathrm{mg}$ protein $)(p$ $=0.03$, paired Student's $t$ test, one tailed).

Having demonstrated a kindling-induced increase in the $B_{\max }$ for ${ }^{3} \mathrm{H}$-CPP specific to CA3 1 month after the last kindled seizure, we queried whether similar increases were detectable $1 \mathrm{~d}$ after the last stimulus-evoked seizure. In contrast to the three- fold increase in $B_{\max }$ detected at $28 \mathrm{~d}$, we found smaller increases in the $B_{\max }(33 \%)$ and in the $K_{D}$ for ${ }^{3} \mathrm{H}-\mathrm{CPP}$ in region $\mathrm{CA} 3$ of kindled animals (Table 3, Fig. 1); these increases were not statistically significant. In accord with findings at $28 \mathrm{~d}$, no change in the $B_{\max }$ for ${ }^{3} \mathrm{H}-\mathrm{CPP}$ was detectable in membranes from either dentate gyrus or CA1 or in ${ }^{3} \mathrm{H}$-CGS-19755 binding in any region 
Table 2. Effects of kindling on ${ }^{3} \mathrm{H}$-CGS-19755 binding in different hippocampal regions, $28 \mathrm{~d}$ after the last kindled seizure

\begin{tabular}{|c|c|c|c|c|c|c|}
\hline & \multicolumn{2}{|l|}{ FD } & \multicolumn{2}{|l|}{$\mathrm{CA} 3$} & \multicolumn{2}{|l|}{$\mathrm{CAl}$} \\
\hline & $B_{\max }$ & $K_{D}$ & $B_{\max }$ & $K_{n}$ & $B_{\max }$ & $K_{n}$ \\
\hline Control & $2.0 \pm 0.4$ & $46 \pm 13$ & $2.1 \pm 0.4$ & $59 \pm 23$ & $2.0 \pm 0.4$ & $40 \pm 10$ \\
\hline Kindled & $2.3 \pm 0.6$ & $43 \pm 14$ & $2.1 \pm 0.4$ & $66 \pm 16$ & $2.1 \pm 0.2$ & $43 \pm 12$ \\
\hline
\end{tabular}

Details are as in Table 1.

(Table 3; Figs. 1, 2). Binding assays for ${ }^{3} \mathrm{H}-\mathrm{CPP}$ and ${ }^{3} \mathrm{H}-\mathrm{CGS}-$ 19755 were done using aliquots of membrane protein from the same kindled and control animals.

To determine whether kindling alters the potency of these NMDA receptor antagonists in a biochemical measure of NMDA receptor activation (Bonhaus and McNamara, 1988, 1989), we examined the inhibitory effects of CPP and CGS-19755 on glutamate-stimulated ${ }^{3} \mathrm{H}-\mathrm{ICP}$ binding in whole hippocampal membranes isolated from animals $28 \mathrm{~d}$ after the last kindled scizurc. In parallel to the mcasurcs of affinity $\left(K_{D}\right)$ detected with ${ }^{3} \mathrm{H}-\mathrm{CPP}$ and ${ }^{3} \mathrm{H}-\mathrm{CGS}-19755$, we found a significantly decreased potency of CPP in membranes isolated from kindled animals without change in potency of CGS-19755 (Table 4).

Agonist binding to whole hippocampal membranes $28 \mathrm{~d}$ after the last kindled seizure

We previously identified an increased number of binding sites for CPP, TCP, and glycine in whole hippocampal membranes prepared from kindled animals $28 \mathrm{~d}$ after the last kindled seizure (Yeh et al., 1989). To determine whether similar increases were detectable in agonist binding to the NMDA receptor, we examined the NMDA-displaceable $\mathrm{L}^{-}{ }^{3} \mathrm{H}$-glutamate binding to whole hippocampal membranes $28 \mathrm{~d}$ after the last evoked seizure. We found a $36 \%$ increase in the $B_{\max }$ and an $84 \%$ increase in the $K_{D}$ for $\mathrm{L}^{-3} \mathrm{H}$-glutamate in membranes isolated from the hippocampus of kindled animals (Table 5).

\section{Levels of NMDA receptor transcripts in kindled and control hippocampus, $28 \mathrm{~d}$ and $24 \mathrm{hr}$ after the last kindled seizure}

To determine whether the increased NMDA receptor binding in $\mathrm{CA} 3$ is due to increased expression of one or more of the genes encoding NMDA receptors, we measured transcript levels of NMDAR1, NR2A, NR2B, NR2C, and GBP with quantitative in situ hybridization using gene-specific riboprobes. Measurement of transcript levels showed no difference in expression of any of these mRNAs either $28 \mathrm{~d}$ or $24 \mathrm{hr}$ after the last kindled seizure in any region of the hippocampal formation (Figs. 3, 4). Note the variation in signal intensity among NMDAR genes, indicating different levels of expression in the hippocampus (Fig. $3 A-H)$. Signal intensity presumably reflects relative expression since all probes had similar specific activities and sections were exposed to the same film for identical times. In experiments done using an oligonucleotide probe specific for NR2D mRNA, we detected no differences between kindled and control in any hippocampal region at either $24 \mathrm{hr}$ or $28 \mathrm{~d}$ after the last evoked seizure (data not shown); indeed, hippocampal expression levels were very low and could not be quantitated.

\section{Discussion}

Three principal findings emerge from this work. One, kindling induces a marked increase in the expression of an NMDA receptor $\left(\mathrm{NMDAR}_{\mathrm{K}}\right)$ that is novel insofar as it is recognized by one competitive antagonist $\left({ }^{3} \mathrm{H}-\mathrm{CPP}\right)$ but not by another $\left({ }^{3} \mathrm{H}\right.$ CGS-19755). Two, the expression of $\mathrm{NMDAR}_{\mathrm{K}}$ is long lasting and, within the hippocampus, is confined to the CA3 region. Three, differential expression of mRNA transcripts of known NMDA receptor genes does not contribute to the molecular basis of NMDAR

\section{Relationship to previous biochemical studies}

The present findings confirm and extend our previous report of a $47 \%$ increase in the density of ${ }^{3} \mathrm{H}$-CPP binding sites in whole hippocampal membranes isolated $28 \mathrm{~d}$ after the last kindled seizure (Yeh et al., 1989). The greater magnitude of the increase reported here $\left(185 \%\right.$ increase in $B_{\max }$ for $\left.{ }^{3} \mathrm{H}-\mathrm{CPP}\right)$ reflects the enrichment due to the expression of NMDAR $\mathrm{N}_{\mathrm{K}}$ exclusively in region $\mathrm{CA} 3$ and is in excellent agreement with our earlier studies. That is, calculations based upon the density of NMDA receptor sites and the amounts of membrane protein derived from each region predict that a $185 \%$ increase in $B_{\max }$ in CA3 without change in dentate or CAl would be expressed as a $45 \%$ increase in membranes derived from whole hippocampus, a value in excellent accord with the experimentally determined value of $47 \%$. The enrichment afforded by the microdissections also permitted detection of a smaller increase in $B_{\max }$ of ${ }^{3} \mathrm{H}-\mathrm{CPP}$ in CA3 isolated $24 \mathrm{hr}$ after the last seizure.

The present findings stand in sharp contrast to our earlier

Table 3. Effects of kindling on ${ }^{3} \mathrm{H}-\mathrm{CPP}$ binding in different hippocampal regions, $24 \mathrm{hr}$ after the last kindled seizure

\begin{tabular}{|c|c|c|c|c|c|c|}
\hline & \multicolumn{2}{|l|}{ FD } & \multicolumn{2}{|l|}{ C.A3 } & \multicolumn{2}{|l|}{ CAl } \\
\hline & $B_{\max }$ & $K_{D}$ & $B_{\max }$ & $K_{D}$ & $B_{\max }$ & $K_{D}$ \\
\hline Control & $1.8 \pm 0.2$ & $132 \perp 21$ & $1.2 \perp 0.1$ & $103 \perp 33$ & $2.1 \perp 0.2$ & $187 \pm 19$ \\
\hline Kindled & $2.0 \pm 0.3$ & $243 \pm 49$ & $1.6 \pm 0.2$ & $193 \pm 40$ & $2.3 \pm 0.2$ & $305 \pm 47$ \\
\hline
\end{tabular}

Values are mean \pm SE of five pairs of pooled membranes prepared from 10 pairs of control and kindled animals (except for control CA3, $n=4$ ). The unit of $K_{D}$ is $\mathrm{nM}$; the unit of $B_{\max }$ is pmol $/ \mathrm{mg}$ protein. No significant differences were detected between kindled and control in any hippocampal region [two-way ANOVA (region $\times$ treatment)]. 


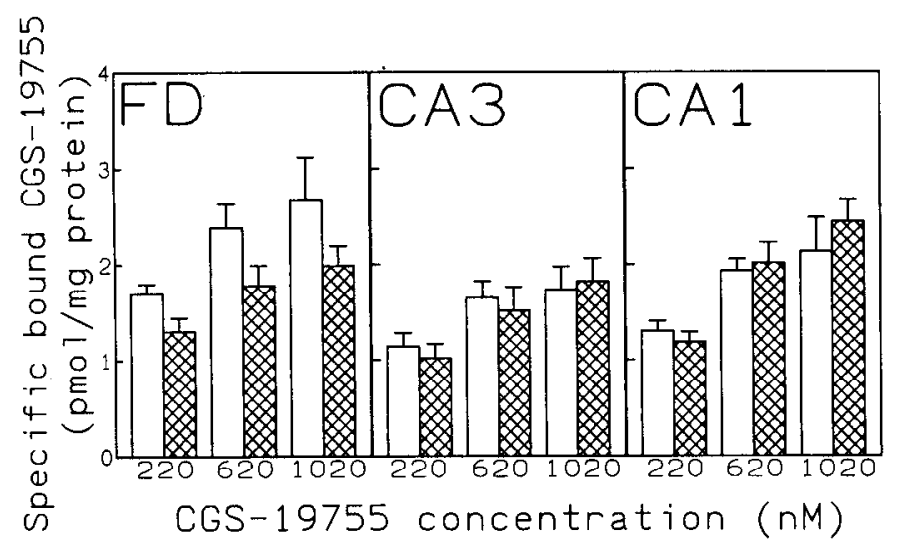

Figure 2. Specific ${ }^{3} \mathrm{H}-\mathrm{CGS}-19755$ binding $24 \mathrm{hr}$ after the last kindled seizure. Bars represent mean $\pm \mathrm{SE}$ of five experiments (except control CA3, $n-4$ ). The difference between kindled and control at each concentration is not significant in any hippocampal region (nonpaired Student's $t$ test, two tailed). Open bars, control; crosshatched bars, kindled.

radiohistochemical study which failed to detect an increase in the specific binding of $\mathrm{L}^{-3} \mathrm{H}$-glutamate to NMDA receptors in CA3 or any other region of hippocampus (Okazaki et al., 1989). At least two factors underlie our earlier negative findings: the choice of ligand and the concentration of ligand. Binding isotherms performed with $\mathrm{L}^{3} \mathrm{H}$-glutamate on hippocampal membranes from kindled rats disclose that the magnitude of the increase of binding to the NMDA receptor is less than that of ${ }^{3} \mathrm{H}$-CPP binding (see Table 5). In addition, the affinity of glutamate (and CPP) for the NMDA receptor is decreased in membranes from kindled animals (Table 5). Since favorable signalto-noise ratios for radiohistochemical studies require use of ligand concentrations at or below the $K_{D}$, these factors render the differences between control and kindled negligible with $\mathrm{L}-{ }^{3} \mathrm{H}-$ glutamate at the concentration used. Likewise, the absence of detectable changes in binding of ${ }^{3} \mathrm{H}$-glycine or ${ }^{3} \mathrm{H}-\mathrm{MK}-801$ to hippocampal membranes of kindled animals (Akiyama et al., 1992) could be explained by the use of a single concentration of radioligand below the $K_{D}$, a condition expected to disclose no differences based upon our binding isotherms with kindled hippocampal membranes using ${ }^{3} \mathrm{H}$-glycine and ${ }^{3} \mathrm{H}-\mathrm{TCP}$ (Yeh et al., 1989).

Three features distinguish the present findings from a large number of radioligand binding studies of kindled animals, namely, the direction, the magnitude, and the time course of the change. Fleeting and relatively small changes (20-60\%) in binding to a diversity of membrane receptors including $\mathrm{GABA}_{\mathrm{A}}$, benzodiazepine, kainate, quisqualate, and muscarinic cholinergic receptors have been identified following a series of kindled seizures (Savage et al., 1984a,b; Shin et al., 1985; Okazaki et al., 1990). Putative localization of each receptor to discrete populations of neurons within the hippocampal formation has been accomplished with quantitative radiohistochemical methods. If the direction of the change in receptor binding is an accurate predictor of a change in synaptic efficacy [e.g., if an increase of $\mathrm{GABA}_{\mathrm{A}}$ receptor binding on the dentate granule cells predicts an increased efficacy of synapses using these receptors, as has been found (Otis and Mody, 1993)], then the net effect of regulation of each of these receptors would be to increase synaptic inhibition or decrease synaptic excitation of principal neurons in the hippocampal formation. In each instance the above changes
Table 4. Effect of kindling on CPP and CGS-19755 inhibition of glutamate-stimulated ${ }^{3} \mathrm{H}$-TCP binding, $28 \mathrm{~d}$ after the last kindled seizure

\begin{tabular}{lll} 
& \multicolumn{1}{l}{$\mathrm{IC}_{50}(\mu \mathrm{M})$} & \\
\cline { 2 - 3 } CPP & CGS-19755 \\
\hline Kindled & $3.3(2.2-5.3)$ & $2.4(1.6-3.6)$ \\
& $7.0(5.1-9.7)^{*}$ & $2.2(1.6-3.1)$
\end{tabular}

The values of $\mathrm{IC}_{50}$ are means, with $95 \%$ confidence limits in parentheses, of six pairs of kindled and control animals.

* The $\mathrm{IC}_{30}$ for CPP inhibition of glutamate-stimulated ${ }^{3} \mathrm{H}-\mathrm{TCP}$ binding measured in whole hippocampal membranes isolated from kindled animals is significantly higher than controls ( $p<0.05$, nonpaired Student's $t$ test).

are detectable in animals killed $1 \mathrm{~d}$ but not 1 month after the last kindled seizure. The direction of the changes combined with the time course indicates that these likely underlie adaptive responses aimed at reducing the likelihood of another seizure. By contrast, the present findings demonstrate a long-lasting, large-magnitude, increased expression of a receptor subserving excitatory synaptic transmission. Such a lasting alteration, coupled with the parallel enhanced sensitivity to NMDA in CA3 pyramidal neurons of kindled animals discussed below, suggests that $\mathrm{NMDAR}_{\mathrm{K}}$ may contribute to a long-lasting enhanced efficacy of glutamatergic synaptic activation of CA3 pyramidal cells in the kindled brain. The absence of detectable findings in fascia dentata indicates that these changes do not explain the altered properties of NMDA receptors identified by Köhr et al. (1993).

\section{The molecular basis of $N M D A R_{K}$}

Particularly notable features of $\mathrm{NMDAR}_{\mathrm{K}}$ evident in radioligand binding studies include both an increase of $B_{\max }$ and a decrease of affinity for ${ }^{3} \mathrm{H}-\mathrm{CPP}$, recognition by one NMDA antagonist ( $\left.{ }^{3} \mathrm{H}-\mathrm{CPP}\right)$ but not by a related antagonist $\left({ }^{3} \mathrm{H}-\mathrm{CGS}-\right.$ 19755), and, paralleling the decreased affinity of CPP evident in binding studies, a decreased potency of CPP in antagonizing glutamate-stimulated TCP binding. Perhaps the most plausible explanation for the increased $B_{\max }$ and $K_{D}$ for ${ }^{3} \mathrm{H}-\mathrm{CPP}$ binding is that two CPP binding sites are present in the CA3 region of the kindled hippocampus, one with high affinity and a new one with low affinity for C.PP. Our efforts to resolve this binding into two sites with binding isotherms performed with 14 concentrations of ${ }^{3} \mathrm{H}$-CPP were unsuccessful in large part because of the technical limitations inherent in the limited supply of membranes and the low signal-to-noise ratio at the highest concentrations of ${ }^{3} \mathrm{H}-\mathrm{CPP}$ (J. E. Kraus, unpublished observations). The inability of CGS-19755 to detect the increase of NMDA receptor binding in the kindled hippocampus could be due to

\section{Table 5. Effects of kindling on NMDA-displaceable ${ }^{3} \mathrm{H}$-glutamate binding to whole hippocampal membranes, $28 \mathrm{~d}$ after the last kindled seizure}

\begin{tabular}{lll} 
& $B_{\max }$ & $K_{D}$ \\
\hline Control & $1.4 \pm 0.1$ & $45 \pm 10$ \\
Kindled & $1.9 \pm 0.07^{*}$ & $83 \pm 13^{*}$
\end{tabular}

Values are mean \pm SE of six pairs of kindled and control animals. The unit of $K_{f}$ is $\mathrm{nM}$; the unit of $B_{\max }$ is $\mathrm{pmol} / \mathrm{mg}$ protein

* The $B_{\max }$ and $K_{D}$ are significantly greater in kindled animals ( $p<0.05$, nonpaired Student's $t$ test, two tailed). 

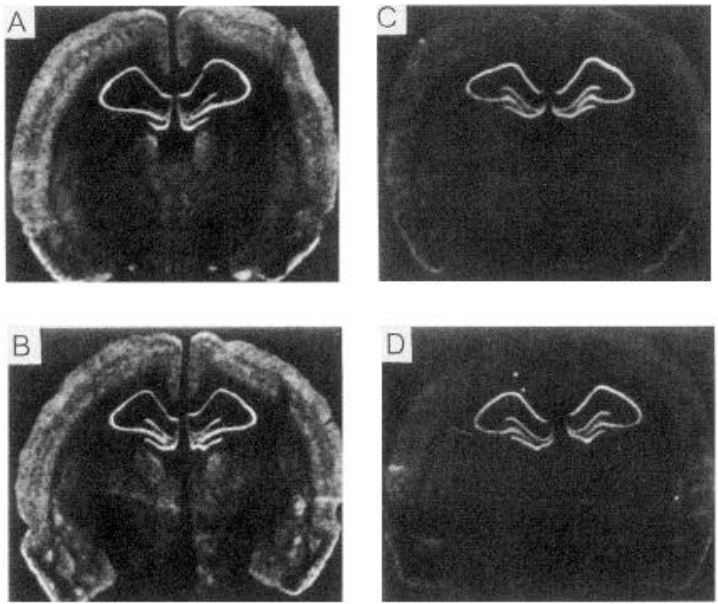
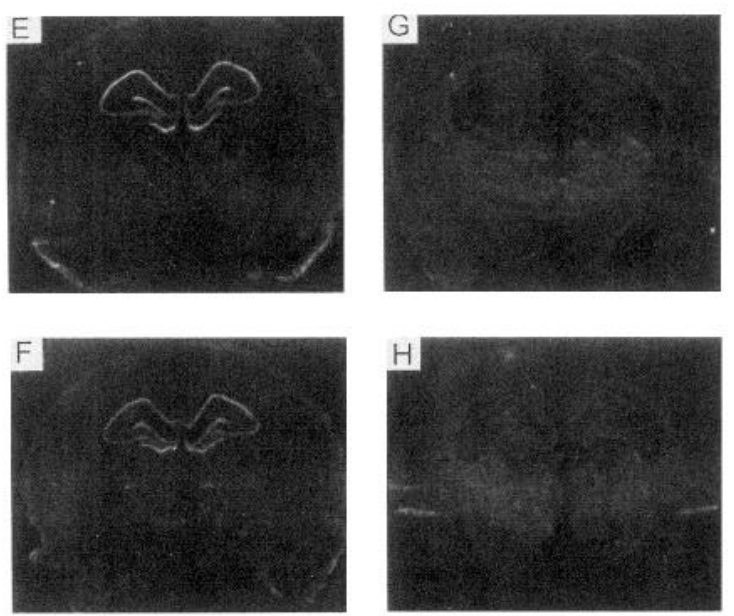
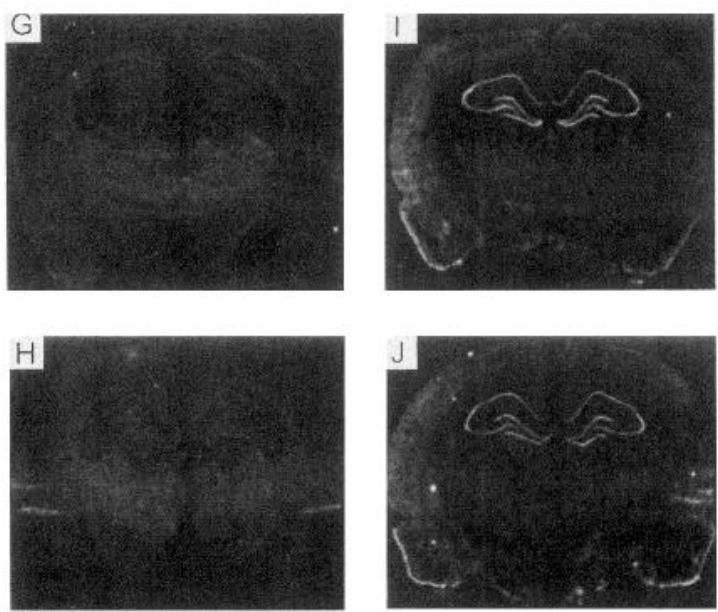

Figure 3. Representative in situ hybridizations of NMDA receptor and GBP probes to kindled and control brain sections, $28 \mathrm{~d}$ after the last kindled seizure. $A$, control NMDAR $1 ; B$, kindled NMDAR $1 ; C$, control NR2A; $D$, kindled NR2A; $E$, control NR2B; $F$, kindled NR2B; $G$, control NR2C; $H$, kindled NR2C; $I$, control GBP; $J$, kindled GBP. Exposure time for GBP was longer than for NMDA receptor genes. For comparisons of relative amounts of each transcript, see Figure 4 . In situ hybridizations done on brain sections prepared $24 \mathrm{hr}$ after the last kindled seizure showed similar patterns of expression.

its having an affinity for $\mathrm{NMDAR}_{\mathrm{K}}$ so low that its binding is not detectable even with centrifugation assays, but this idea could not be directly tested. In any event, the parallel reductions in affinity of CPP binding and of potency of CPP in antagonizing glutamate-stimulated TCP binding, a measure of receptor-regulated channel opening (Bonhaus and McNamara, 1988, 1989), strengthen the likelihood that the changes in ${ }^{3} \mathrm{H}-\mathrm{CPP}$ binding reflect changes in functional receptors. Finally, whereas previous studies of normal brain disclosed differences in NMDA receptors consistent with agonist- or antagonist-preferring subtypes (Monaghan et al., 1988), identification of an NMDA receptor that recognizes one but not another antagonist demonstrates that classification of NMDA receptor subtypes is more complex than simply agonist or antagonist preferring.

The molecular nature of $\mathrm{NMDAR}_{\mathrm{K}}$ and how it differs from NMDA receptors normally present in CA3 are presently unclear. As a first step toward investigating this question, we used quantitative in situ hybridization to measure the mRNA content for known genes encoding the NMDA receptor and for a glutamate-binding protein of presently unknown function. No significant differences in expression of any of these genes were detected in CA3 or other regions of the hippocampal formation in animals killed either $1 \mathrm{~d}$ or 1 month after the last kindled seizure. These do not exclude the possibility that protein levels of known genes are altered by kindling in the absence of underlying changes in mRNA expression (Rogers et al., 1991). Other potential explanations include expression of a presently unknown NMDA receptor gene, a posttranslational modification (Tingley et al., 1993), the presence of a novel protein associated with the receptor (Froehner et al., 1990), or the differential expression of NMDA receptor splice variants (Nakanishi et al., 1992; Sugihara et al., 1992).

Does NMDAR $R_{K}$ underlie the increased potency of NMDAevoked depolarization of CA3 pyramidal cells of kindled hippocampus?

Correlative biochemical and electrophysiological studies support the idea that $\mathrm{NMDAR}_{\mathrm{K}}$ resides, at least in part, in the surface membrane of CA3 pyramidal cells and contributes to the increased sensitivity of these neurons to NMDA. We initially demonstrated that hippocampal neurons of kindled animals exhibit an increased sensitivity to NMDA, since NMDA more potently inhibited carbachol-stimulated phosphoinositide hydrolysis in hippocampal slices isolated $1 \mathrm{~d}$ or 1 month after the last kindled seizure (Morrisett et al., 1989). We subsequently used the grease gap preparation to pinpoint the population of neurons with increased sensitivity to NMDA. We found that CA3 pyramidal cells in slices isolated from kindled animals were fivefold more sensitive to NMDA-evoked depolarizations compared to slices from controls. A significant but much smaller increase was evident in slices isolated $1 \mathrm{~d}$ after the last seizure. The increased sensitivity was found with NMDA but not $\alpha$-amino-3-hydroxyl-5-methyl-4-isoazole propionic acid (AMPA) and was found in CA 3 but not CA1 pyramidal cells. The most plausible explanation of the findings from the grease gap studies was an increase in the number of NMDA receptors in the membrane of CA3 pyramidal cells (Martin et al., 1992). The present findings fulfill several predictions of the grease gap studies: (1) the direction of the change in binding, an increase; (2) the time course (present both $1 \mathrm{~d}$ and 1 month, but greater at 1 month after the last seizure); and (3) the localization to the CA3 region but not CA1 region. In addition, paralleling the reduced affinity of CPP in binding studies is a reduction in the potency of CPP in antagonizing NMDA-evoked depolarizations (J. V. Nadler et al., unpublished observations). One unresolved discrepancy is that CGS-19755 is less potent in blocking NMDA-evoked depolarizations in CA3 of kindled animals (Nadler et al., 1994) yet exhibits no detectable differences in affinity in binding assays. This discrepancy notwithstanding, the remarkable correlation between the findings with the binding and grease gap argues that $\mathrm{NMDAR}_{K}$ underlies the increased sensitivity of CA3 pyramidal cells to NMDA.

\section{Implications for cellular excitability and seizure propagation through neuronal networks}

The localization of this long-lasting increase of $\mathrm{NMDAR}_{K}$ to CA3 in particular strengthens the idea that this receptor may contribute to the lasting propensity of the kindled brain to express a seizure. The hippocampus is an especially seizure-prone region of the brain (Green, 1964) and within the hippocampus 


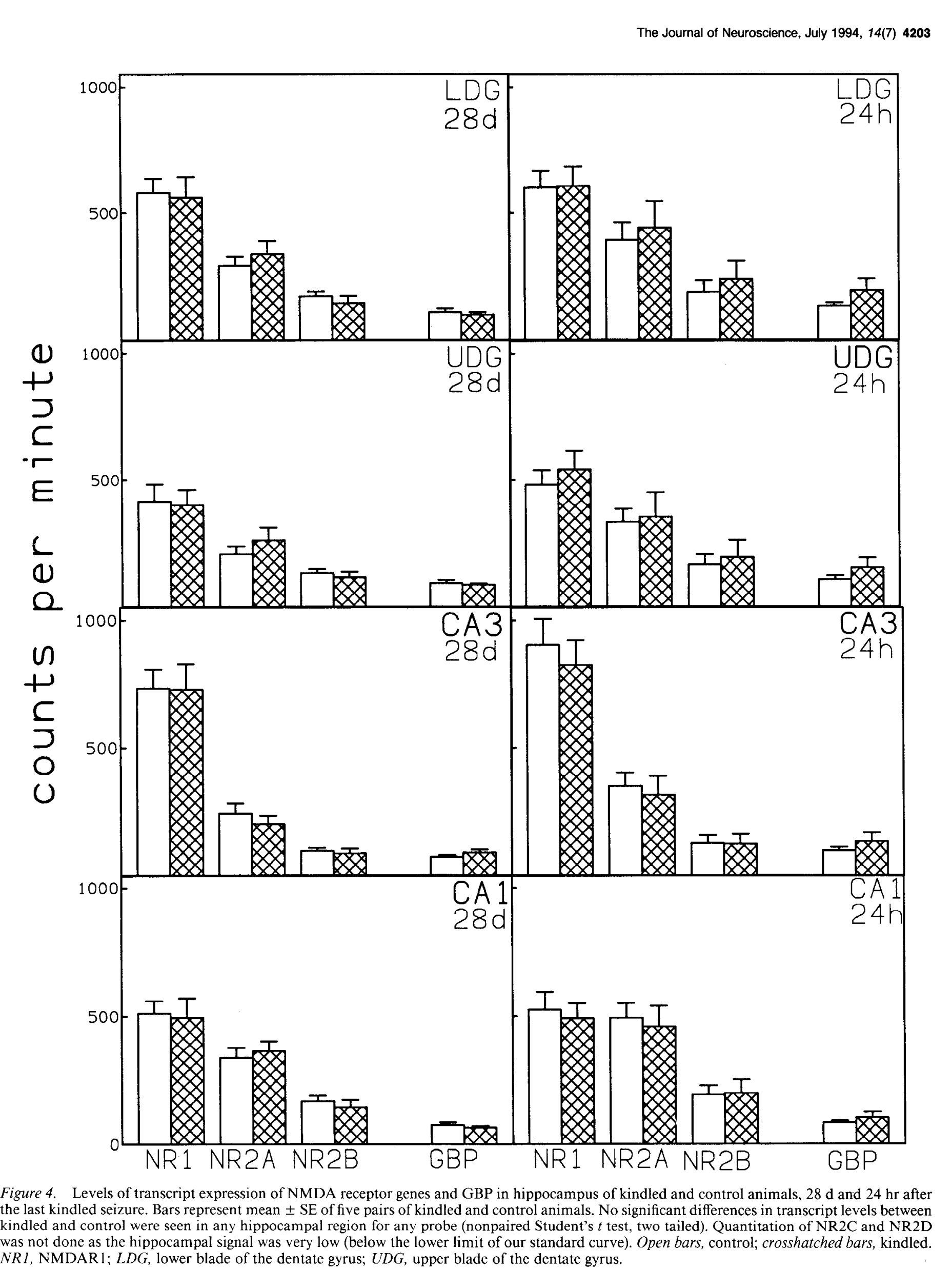




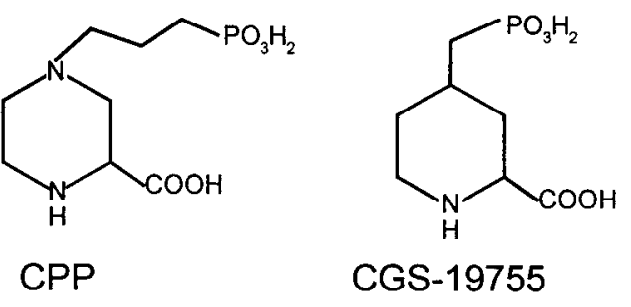

Figure 5. Structures of CPP and CGS-19755.

the CA3 pyramidal cells are the most prone to exhibit epileptiform activity in slices studied in vitro (King et al., 1985; Dingledine et al., 1986). Study of the isolated guinea pig brain in vitro suggests that re-entrant loop activity in the hippocampalentorhinal circuit is the central event in the functional organization of hippocampal seizure discharges (Paré et al., 1992). Interestingly, the initial seizure discharges in this loop usually occurred in the CA3 region, with neuronal populations then firing sequentially in $\mathrm{CA} 1$, entorhinal cortex, and so on. The question arises as to whether expression of $\mathrm{NMDAR}_{\mathrm{K}}$ might further predispose an already seizure-prone population of neurons in CA3 to express a seizure, the hallmark of a kindled animal. Computer simulations suggest a mechanism by which a novel NMDA receptor expressed in CA3 might facilitate initiation of seizure activity. These simulations indicate that the transition from interictal spikes to ictal bursting of CA3 pyramidal cells would be markedly facilitated by an increased and sustained NMDA receptor conductance, resulting in an increased $\mathrm{Ca}^{2+}$ influx in the apical dendrites (Traub et al., 1993). It seems plausible that $\mathrm{NMDAR}_{\mathrm{K}}$ may reside, at least in part, in the apical dendrites of the CA3 pyramidal cells and, if so, could contribute to the lasting propensity of the kindled brain to express a seizure. If, as seems likely, the expression of NMDAR ${ }_{K}$ is also increased at sites in the kindled brain outside the hippocampus, interactions among these multiple sites could be positively reinforcing and could promote the expression of a kindled seizure. The fact that systematically administered NMDA antagonists inhibit kindled seizures is consistent with these ideas.

\section{Therapeutic implications of $N M D A R_{K}$.}

A major shortcoming of NMDA receptor antagonists with respect to development of a clinically effective anticonvulsant lies in the multitude of unwanted effects of these agents arising from the blockade of NMDA receptors mediating a diversity of physiologic functions. If $\mathrm{NMDAR}_{\mathrm{K}}$ serves a pivotal role in the expression of kindled seizures, the molecular specificity of $\mathrm{NMDAR}_{\mathrm{K}}$ may permit development of antagonists that inhibit $\mathrm{NMDAR}_{\mathrm{K}}$ but not other NMDA receptors. The remarkable molecular specificity of $\mathrm{NMDAR}_{K}$ is evident in the comparison of the structures of two competitive antagonists (CPP and CGS19755), only one of which (CPP) recognizes $\mathrm{NMDAR}_{K}$. These antagonists exhibit two differences: the presence of a nitrogen atom in the ring structure and the presence of two additional methyl moieties in their hydrocarbon side chain (Fig. 5). Elucidating the molecular basis by which $N_{M D A R}$ recognizes $C P P$ but not CGS-19755 may permit development of a new class of NMDA antagonists that are highly selective in their blockade

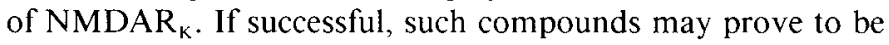
clinically effective anticonvulsant agents.

\section{References}

Akiyama K, Yoneda Y, Ogita K, Itoh T, Daigen A, Sora I, Kohira I, Ujike H, Otsuki S (1992) Brain Res 587:73-82.

Bonhaus DW, McNamara JO (1988) $N$-methyl-D-aspartate receptor regulation of uncompetitive antagonist binding in rat brain membranes: kinetic analysis. Mol Pharmacol 34:250-255.

Bonhaus DW, McNamara JO (1989) TCP binding: a tool for studying NMDA receptor-mediated neurotransmission in kindling. Neurosci Biobehav Rev 13:261-267.

Bonhaus DW, Yeh G-C, Skaryak L, McNamara JO (1989) Glycine regulation of $N$-methyl-D-aspartate receptor-gated ion channel in hippocampal membranes. Mol Pharmacol 36:273-279.

Cain DP, Desborough KA, McKitrick DJ (1988) Retardation of amygdala kindling by antagonism of $N$-methyl-D-aspartate and muscarinic cholinergic receptors: evidence for summation of excitatory mechanisms in kindling. Exp Neurol 100:179-187.

Callaghan DA, Schwark WS (1980) Pharmacological modification of amygdaloid-kindled seizures. Neuropharmacology 19:1131-1136.

Deuchars J, Thomson AM (1993) Synapses and receptors: a molecular perspective in honour of Professor E. A. Barnard. Trends Neurosci $16: 43-45$.

Dingledine R, Hynes MA, King GL (1986) Involvement of $N$-methylD-aspartate receptors in epileptiform bursting in the rat hippocampal slice. J Physiol (Lond) 380:175-189.

Froehner SC, Luetje CW, Scotland PB, Patrick J (1990) The postsynaptic $43 \mathrm{~K}$ protein clusters muscle nicotinic acetylcholine receptors in Xenopus oocytes. Neuron 5:403-410.

Goddard GV, McIntyre EC, Leech CK (1969) A permanent change in brain function resulting from daily electrical stimulation. Exp Neurol 25:295-330.

Green JD (1964) The hippocampus. Physiol Rev 44:561-608.

Holmes KH, Goddard GV (1986) A role for the $N$-methyl-D-asparate in kindling. Proc Univ Otago Med Sch 64:37-39.

Holmes KH, Bilkey DK, Laverty R, Goddard GV (1990) The $N$-methyl-D-aspartate antagonists aminophosphonovalerate and carboxypiperazinephosphonate retard the development and expression of kindled seizures. Brain Res 506:227-235.

Ikeda K, Nagasawa M, Mori H, Araki K, Sakimura K, Watanabe M, Inoue Y, Mishina M (1992) Cloning and expression of the $\epsilon 4$ subunit of the NMDA receptor channel. FEBS Lett 313:34-38.

Ishii T, Moriyoshi K, Sugihara H, Sakurada K, Kadotani H, Yokoi M, Akazawa C, Shigemoto R, Mizuno N, Masu M, Nakanishi S (1993) Molecular characterization of the family of the $N$-methyl-D-aspartate receptor subunits. J Biol Chem 268:2836-2843.

King GL, Dingledine R, Giacchino JL, McNamara JO (1985) Abnormal neuronal excitability in hippocampal slices from kindled rats. J Neurophysiol 54:1295-1304.

Köhr G, De Koninck Y, Mody I (1993) Properties of NMDA receptor channels in neurons acutely isolated from epileptic (kindled) rats. $J$ Neurosci 13:3612-3627.

Kraus JE, Yeh G-C, Bonhaus DW, Watanabe Y, Nadler JV, McNamara JO (1993) Induction of a novel NMDA receptor by kindling in CA3 is not related to alterations in NMDAR transcript levels. Soc Neurosci Abstr 19:925.

Kumar KN, Tilakaratne N, Johnson PS, Allen AE, Michaelis EK (1991) Cloning of cDNA for the glutamate-binding subunit of an NMDA receptor complex. Nature 354:70-73.

Kutsuwada T, Kashiwabuchi N, Mori H, Sakimura K, Kushiya E, Araki K, Meguro H, Masaki H, Kumanishi T, Arakawa M, Mishina M (1992) Molecular diversity of the NMDA receptor channel. Nature $358: 36-41$.

Löscher W, IIönack D (1991) Anticonvulsant and behavioral effects of two novel competitive $N$-methyl-D-aspartic acid receptor antagonists, CGP 37849 and CGP 39551, in the kindling model of epilepsy: comparison with MK-801 and carbamazepine. J Pharmacol Exp Ther 256:432-440.

Lowry OH, Rosebrough NJ, Farr AL, Randall RJ (1951) Protein measurement with the folin phenol reagent. J Biol Chem 193:265275.

Martin D, McNamara JO, Nadler JV (1992) Kindling enhances sensitivity of CA3 hippocampal pyramidal cells to NMDA. J Neurosci 12:1928-1935.

McNamara JO, Russel RD, Rigsbee L, Bonhaus DW (1988a) Anticonvulsant and anti-epileptogenic actions of MK-801 in the kindling and electroshock models. Neuropharmacology 27:563-568. 
McNamara JO, Bonhaus DW, Shin C (1988b) Mechanisms of kindling: a speculative hypothesis. In: Mechanisms of epileptogenesis (Dichter MA, ed), pp 85-99. New York: Plenum.

McNamara JO, Morrisett R, Nadler JV (1992) Recent advances in understanding mechanisms of the kindling model. Adv Neurol 57: 555-560.

McPherson GA (1985) A collection of radioligand binding analysis programs. Amsterdam: Elsevier.

Meguro H, Mori H, Araki K, Kushiya E, Kutsuwada T, Yamazaki M, Kumanishi T, Arakawa M, Sakimura K, Mishina M (1992) Functional characterization of a heteromeric NMDA receptor channel expressed from cloned cDNAs. Nature 357:70-74.

Mody I, Stanton PK, Heinneman U (1988) Activation of $N$-methyl$\mathrm{D}$-aspartate receptors parallels changes in cellular and synaptic properties of dentate granule cells after kindling. J Neurophysiol 59:10331054.

Monaghan DT, Olverman HJ, Nguyen L, Watkins JC, Cotman CW (1988) Two classes of $N$-methyl-D-aspartate recognition sites: differential distribution and differential regulation by glycine. Proc Natl Acad Sci USA 85:9836-9840.

Monyer H, Sprengel R, Schoepfer R, Herb A, Higuchi M, Lomeli H, Burnashev N, Sakmann B, Seeburg PH (1992) Heteromeric NMDA receptors: molecular and functional distinction of subtypes. Science 256:1217-1221.

Monyer H, Laurie DJ, Seeburg PH (1993) Ontogeny of NMDA receptors in the rat brain. Soc Neurosci Abstr 19:648.

Moriyoshi K, Masu M, Ishii T, Shigemoto R, Mizuno N, Nakanishi S (1991) Molecular cloning and characterization of the rat NMDA receptor. Nature 354:31-37.

Morrisett RA, Chow C, Nadler JV, McNamara JO (1989) Biochemical evidence for enhanced sensitivity to $N$-methyl-D-aspartate in the hippocampal formation of kindled rats. Brain Res 496:25-28.

Morrisett RA, Chow C, Sakaguchi T, Shin C, McNamara JO (1990) Inhibition of muscarinic-coupled phosphoinositide hydrolysis by $\mathrm{N}$-methyl-D-aspartate is dependent upon depolarization via channel activation. J Neurochem 54:1517-1525.

Nadler JV, Thompson MA, McNamara JO (1994) Kindling reduces sensitivity of CA3 hippocampal pyramidal cells to competitive NMDA receptor antagonists. Neuropharmacology, in press.

Nakanishi N, Axel A, Schneider NA (1992) Alternative splicing generates functionally distinct $N$-mcthyl-D-aspartate receptors. Proc Natl Acad Sci USA 89:8552-8556.

Nakanishi S (1992) Molecular diversity of glutamate receptors and implications for brain function. Science 258:597-603.

Okazaki MM, McNamara JO, Nadler JV (1989) $N$-methyl-D-aspartate receptor autoradiography in rat brain after angular bundle kindling. Brain Kes 482:354-364.

Okazaki MM, McNamara JO, Nadler JV (1990) Kainate and quisqualate receptor autoradiography in rat brain after angular bundle kindling. Neuroscience 37:135-142.
Otis TS, Mody I (1993) Three mechanisms for increased GABAergic inhibition after kindling-induced epilepsy. Soc Neurosci Abstr 19: 1267.

Paré D, deCurtis M, Llinás R (1992) Role of the hippocampal-entorhinal loop in temporal lobe epilepsy: extra- and intracellular study in the isolated guinea pig brain in vitro. J Neurosci 12:1867-1881.

Paxinos G, Watson C (1986) The rat brain in stereotactic coordinates, 2 d ed. New York: Academic.

Peterson DW, Collins JF, Bradford HF (1983) The kindled amygdala model of epilepsy: anticonvulsant action of amino acid antagonism. Brain Res 275:169-172.

Peterson DW, Collins JF, Bradford HF (1984) Anticonvulsant action of amino acid antagonists against kindled hippocampal seizures. Brain Res 311:176-180.

Racine RJ (1972) Modulation of seizure activity by electrical stimulation. II. Motor seizure. Electroencephalogr Clin Neurophysiol 32: 281-294.

Raymond LA, Blackstone CD, Huganir RL (1993) Phosphorylation and modulation of recombinant GluR6 receptors by cAMP-dependent protein kinase. Nature 361:637-641.

Rogers SW, Hughs TE, Hollmann M, Gasic GP, Deneris ES, Heinemann S (1991) The characterization and localization of the glutamate receptor subunit GluR 1 in the rat brain. J Neurosci 11:2713-2724.

Savage DD, Werling LL, Nadler JV, McNamara JO (1984a) Selective and reversible increase in the number of quisqualate-sensitive glutamate binding sites on hippocampal synaptic membranes after angular bundlc kindling. Brain Res 307:332-335.

Savage DD, Nadler JV, McNamara JO (1984b) Reduced kainate acid binding in rat hippocampal formation after limbic kindling. Brain Res 323:128-131.

Shin C, Pedersen HB, McNamara JO (1985) $\gamma$-Aminobutyric acid and benzodiazepine receptors in the kindling model of epilepsy: a quantitative radiohistochemical study. J Neurosci 5:2696-2701.

Sugihara H, Moriyoshi K, Ishii T, Masu M, Nakanishi S (1992) Structures and properties of seven genes of the NMDA receptor generated by alternative splicing. Biochem Biophys Res Commun 185:826-836.

Tingley WG, Roche KW, Thompson AK, Huganir RL (1993) Regulation of NMDA receptor phosphorylation by alternative splicing of the C-terminal domain. Nature 364:70-73.

Traub RD, Miles R, Jefferys JGR (1993) Synaptic and intrinsic conductances shapc picrotoxin-induced synchronized after-discharges in the guinea-pig hippocampal slice. J Physiol (Lond) 461:525-547.

Wisden W, Morris BJ, Hunt SP (1991) In situ hybridization with synthetic DNA probes. In: Molecular neurobiology: a practical approach (Chad J, Wheal H, eds), pp 205-225. New York: IRL Press at Oxford UP.

Yeh G-C, Bonhaus DW, Nadler JV, McNamara JO (1989) $N$-methyl$\mathrm{D}$-aspartate receptor plasticity in kindling: quantitative and qualitative alterations in the $N$-methyl-D-aspartate receptor-channel complex. Proc Natl Acad Sci USA 86:8157-8160. 